\title{
OECD DAC 통계작업반 비공식회의 및 워크샵
}

\section{I. 회의 개요}

$\mathrm{OECD} \mathrm{DAC}$ 통계작업반 비공식회의 및 워크샵이 2012년 2월 1일 부터 3일까지 오스트리아 개발 은행에서 개최됨.

\section{II. 주요내용}

- 6월 통계작업반 본회의에서 ODA 적격 국제기구 목록(통계지침 Annex2) 중 '기타다자기 구(채널코드 47000)'를 개정하기 위하여 사무국 제안문서에 대한 의견을 2월 29일(수)까 지 서면으로 제출할 것을 요청함.

- UNDPKO에 대한 분담금 납부 이외에 양자적으로 군부대를 파병하는 비용은 ODA에서 제외된다는 내용을 통계지침에 명시하자는 사무국 제안에 이견이 있을 경우 2월 29일(수) 까지 서면 제출을 요구하였고, 이견이 없을 시 승인과 동시에 통계지침이 개정됨을 공지함.

- 사무국은 캄보디아전범재판소 $(\mathrm{ECCC})$ 를 $\mathrm{ODA}$ 적격 기구에 포함하고 국제의약품기구 (UNITAID)의 카테고리 변경 $(\mathrm{PPP} \rightarrow$ 다자기구)에 대한 이견이 있을 시 2월 10일(금)까지 서면 제출할 것을 요청하였고, 이견이 없을시 바로 승인된다고 안내함.

- 사무국은 부산세계개발원조 총회에서 채택된 부산선언 중 투명성과 관련한 통계작업반의 역할을 소개하고, 투명성 이행을 위한 국제 원조 투명성 이니셔티브(IATI: International Aid Transparency Initiative)와의 협업 문제 등을 논의하였으나 합의를 도출하지 못하 여 6월 회의 시 재논의하기로 결정함.

\section{III. 관찰 및 평가/건의}

- 기타다자기구 개정(안)은 회원국의 서면 검토(2월말 기한)를 반영하여 6월 본회의에서 승 인할 계획인 바, 우리는 2013년 글로벌녹색성장연구소(GGGI)를 ODA 적격기구로 신청 예정임을 감안하여 동 개정(안)에 대한 면밀한 검토가 요구됨. 특히 현재 INGO 신규 등재 경우에만 적용되는 예산 범위(연간 예산 5 천만불 이상 기구만 가능)가 다자기구에 확대 적 용될 가능성이 있는지 지속적으로 점검해야 할 것임.

- $\mathrm{ECCC}$ 의 ODA 적격기구 포함, UNITAID 카테고리 변경 및 UNDPKO에 군부대 파병비용 제외 항목의 지침 명시 등은 서면 검토 후 즉시 승인 · 적용 예정인 바, 2011년 실적보고시 부터 반영될 수 있도록 결정 사항을 관련 기관에 적의 공지해야 할 것임.

- 통계작업반은 인권 관련 기구에 대한 $\mathrm{ODA}$ 적격성 여부 평가 기준을 정립하여 통계보고지 침에 포함하려는 작업의 일환으로 개발관점의 인권 활동에 대한 회원국의 서면 검토를 2 월 말까지 요청한 바, 우리나라가 지원하는 인권기구들이 ODA 적격으로 포함될 수 있는 기 준이 만들어 질 수 있도록 관련 기관의 적극적인 검토가 요구됨. 